Jurnal Progres Ekonomi Pembangunan (JPEP)

Volume 5, Nomor 1, Tahun 2020

Page: $71-82$

http://ojs.uho.ac.id/index.php/JPEP

\title{
PENGARUH KESADARAN WAJIB PAJAK DAN AKUNTABILITAS PELAYANAN PUBLIK TERHADAP KEPATUHAN WAJIB PAJAK KENDARAAN BERMOTOR PADA KANTOR SAMSAT KOTA KENDARI \\ Nofian Lepong Bulan \\ Pascasarjana UHO
}

Husin

Fakultas Ekonomi dan Bisnis Universitas Halu Oleo Kendari

La Ode Anto

Fakultas Ekonomi dan Bisnis Universitas Halu Oleo Kendari

\begin{abstract}
ABSTRAK
Tujuan penelitian ini adalah sebagai berikut: (1) Untuk mengetahui dan menganalisis pengaruh kesadaran wajib pajak terhadap kepatuhan wajib pajak, (2) Untuk mengetahui dan menganalisis pengaruh pengetahuan pajak kepatuhan wajib pajak, (3) Untuk mengetahui dan menganalisis pengaruh sanksi pajak, terhadap kepatuhan wajib pajak, (4) Untuk mengetahui dan menganalisis pengaruh akuntabilitas pelayanan publik terhadap kepatuhan wajib pajak pada Kantor Samsat Kota Kendari

Jenis penelitian yang dilakukan adalah penelitian dasar (basic research). Populasi sebanyak 115.240 wajib pajak, penentuan sampel digunaka rumus Slovin sehingga jumlah sampel dalam penelitian ini sebanyak 90 responden. Analisis yang digunakan adalah regresi linear berganda.

Berdasarkan hasil analisa dan pembahasan dalam penelitian ini, maka dapat ditarik beberapa kesimpulan sebagai berikut: (1) Kesadaran wajib pajak, Akuntabilitas pelayanan publik secara bersama-sama berpengaruh terhadap kepatuhan wajib, (2) Kesadaran wajib pajak secara parsial berpengaruh terhadap kepatuhan wajib pajak. (3) Akuntabilitas pelayanan publik secara parsial berpengaruh terhadap kepatuhan wajib pajak kendaraan bermotor pada kantor samsat Kota Kendari.

Kata kunci : Kesadaran wajib pajak, Akuntabilitas pelayanan publik
\end{abstract}

\section{PENDAHULUAN}

\subsection{Latar Belakang}

Peran pajak sebagai penerimaan dalam negeri sangat dominan, namun masih belum optimal jika dilihat dari banyaknya Wajib Pajak yang belum menjadi Wajib Pajak patuh. Kebersamaan nasional menuju kemandirian pembangunan menuntut pengabdian dan disiplin yang tinggi. Oleh karena itu, setiap rakyat Indonesia harus sadar bahwa dengan semakin menikmati hasil-hasil pembangunan maka tanggung jawab rakyat terhadap pajak dalam pelaksanaan pembangunan semakin besar. Kesadaran akan tanggung jawab ini menjadi nilai yang fundamental dalam pembangunan dan diharapkan kepatuhan pajak dapat diwujudkan.

Susanto Herry (2012) kesadaran dan kepedulian sukarela Wajib Pajak sangat sulit untuk diwujudkan. Sampai sekarang masyarakat membayar pajak belum mencapai tingkat sebagaimana yang diharapkan. Namun masih ada upaya yang dapat dilakukan sehingga masyarakat sadar sepenuhnya untuk membayar pajak. Ketika masyarakat memiliki kesadaran, maka membayar pajak akan dilakukan secara sukarela bukan keterpaksaan.

Pajak Kendaraan Bermotor (PKB) kepada Wajib Pajak yang tidak melakukan pembayaran sesuai jatuh tempo yang terdapat pada Surat Ketetapan Pajak Daerah (SKPD). Berdasarkan kewenangannya, pajak dapat dibedakan sebagai pajak pusat dan pajak daerah. Mengenai pajak daerah, peranannya sangat penting sebagai sumber pendapatan daerah dan sebagai penopang pembangunan daerah karena pajak daerah merupakan salah satu sumber Pendapatan Asli Daerah (PAD). Dengan dikeluarkannya Undang-Undang Nomor 28 Tahun 2009 tentang perubahan atas Undang-Undang Nomor 34 Tahun 2000 tentang Pajak Daerah dan Retribusi Daerah. Pemberian kewenangan dalam pengenaan pajak dan retribusi daerah, diharapkan dapat lebih mendorong 
Jurnal Progres Ekonomi Pembangunan (JPEP)

Volume 5, Nomor 1, Tahun 2020

Page: $71-82$

http://ojs.uho.ac.id/index.php/JPEP

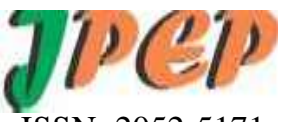

e-ISSN: 2052-5171

pemerintah daerah terus berupaya untuk mengoptimalkan pendapatan asli daerah (PAD), khususnya yang berasal dari pajak daerah yaitu pajak kendaraan bermotor (PKB).

Pengenaan pajak pada tiap wajib pajak akan berbeda sesuai peraturan perpajakan yang berlaku. Dalam hal ini, wajib pajak dibagi menjadi wajib pajak orang pribadi dan wajib pajak badan. Wajib pajak orang pribadi terdiri dari wajib pajak sebagai usahawan atau pekerja bebas dan non usahawan. Bagi wajib pajak non usahawan dalam hal perpajakannya biasanya sudah dihitungkan oleh bendaharawan tempat instansi wajib pajak non usahawan bekerja sedangkan wajib pajak usahawan dan pekerja bebas harus merekap peredaran bruto, menghitung pajaknya berdasarkan tarif pajak tertentu, dan melaporkannya ke Ditjen Pajak atas penghasilannya sendiri pada masa pajak tertentu. Berkaitan dengan hal tersebut, penulis mengambil sampel dalam penelitian ini adalah Wajib Pajak Orang Pribadi yang memiliki usaha dan pekerja bebas yang terdaftar di KPP Pratama Kota Kendari.

Ilhamsyah (2016) yang harus dirubah dalam pemikiran masyarakat ada beberapa hal, salah satunya prasangka buruk masyarakat. Prasangka buruk masyarakat terhadap petugas pajak harus dirubah menjadi prasangka yang baik, untuk merubah hal tersebut tentu harus menciptakan pelayanan yang memuaskan dan berkualitas. Menurut Feld dan Frey (2007:110), Masyarakat akan membayar pajak dari penghasilan yang diterimanya apabila mereka merasakan pelayanan publik sebanding dengan pembayaran pajaknya, adanya perlakuan yang adil dari pemerintah serta proses perpajakan yang jelas dari pemerintah.

Kepatuhan wajib pajak dapat dipengaruhi oleh beberapa faktor, yaitu kondisi sistem administrasi perpajakan suatu Negara, pelayanan pada wajib pajak, penegakan hukum perpajakan, pemeriksaan pajak, dan tarif pajak (Devano dan Rahayu, 2006:112 dalam Isnaini, 2015). Selain itu, menurut Aristanti Widyaningsih (dalam Vivi Yulian Sari dan Neri Susanti, 2013) mengemukakan bahwa ada beberapa faktor yang mempengaruhi kepatuhan wajib pajak yaitu pemahaman terhadap sistem Self Assessment, kualitas pelayanan, tingkat pendidikan, tingkat penghasilan dan persepsi wajib pajak terhadap sanksi perpajakan. Apabila semua faktor-faktor tersebut dapat diaplikasikan dalam sistem perpajakan, maka bukan hal yang mustahil kepatuhan perpajakan dapat terwujud.

Kantor UPPD/SAMSAT Kota Kendari sebagai tempat bagi wajib pajak kendaraan bermotor membayar pajak, selalu berusaha memberikan pelayanan publik yang berkualitas dan terbaik agar meningkatkan kepatuhan wajib pajak. Pajak kendaraan online SAMSAT kota Kendari merupakan salah satu pelayanan yang disediakan oleh kantor UPPD/SAMSAT kota Kendari. Layanan ini diadakan dengan tujuan untuk memudahkan wajib pajak dalam membayar pajak kendaraan bermotornya. Pemberian pelayanan yang baik oleh petugas pajak akan memunculkan perasaan senang dan puas yang dapat memicu motivasi dan kepatuhan wajib pajak.

Penelitian yang dilakukan oleh I Wayan Mustika Utama (2015) pengaruh kualitas pelayanan, sanksi perpajakan dan biaya kepatuhan terhadap kepatuhan wajib pajak. pengembangan penelitian ini I Wayan Mustika Utama (2015) atas saran penelitian ini meningkatkan penegakan sanksi pajak sesuai dengan aturan perpajakan yang berlaku agar wajib pajak lebih patuh dalam pembayar pajak kedaraan bermotor. Kedua penelitian yang dilakukan oleh Derwiza Ertrivana (2016) pengaruh kesadaran wajib pajak, pengetahuan pajak dan sanksi perpajakan terhadap kepatuhan wajib pajak kendaraan bermotor Derwiza Ertrivana (2016) atas saran penelitian selanjutnya agar dapat meneliti di kabupaten atau di kota.

Winda Kemala (2016) pengaruh kesadaran wajib pajak, pengetahuan pajak, sikap wajib pajak dan reformasi administrasi Perpajakan terhadap kepatuhan wajib pajak Kendaraan bermotor Winda Kemala (2016) atas saran penelitian selanjutnya untuk memperluas seluruh wajib pajak kendaraan bermotor yang terdaftar di Kendari bersama SAMSAT di provinsi. 
Jurnal Progres Ekonomi Pembangunan (JPEP)

Volume 5, Nomor 1, Tahun 2020

Page: $71-82$

http://ojs.uho.ac.id/index.php/JPEP

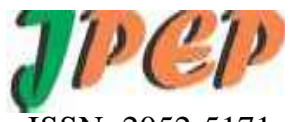

e-ISSN: 2052-5171

Penelitian ini bertujuan untuk menganalisis dan mengetahui: (1) pengaruh kesadaran wajib pajak berpengaruh terhadap kepatuhan wajib pajak pada Kantor Samsat Kota Kendari dan (2) pengaruh akuntabilitas pelayanan publik terhadap kepatuhan wajib pajak pada Kantor Samsat Kota Kendari.

\section{KAJIAN LITERATUR DAN HIPOTESIS \\ 2.1. Theory of Planned Behavior}

Ajzen mengembangkan theory of planned behavior (TPB) ini pada tahun 1988. Ajzen (1988) menambahkan sebuah konstruk yang belum ada di theory of reasoned action (TRA). Konstruk ini disebut dengan control perilaku persepsian. Konstruk ini ditambahkan di TPB untuk mengontrol perilaku individual yang dibatasi oleh kekurangan-kekurangannya dan keterbatasanketerbatasan dari kekurangan sumber-sumber daya yang digunakan untuk melakukan perilakunya. Jogiyanto (2007:61) menjelaskan teori perilaku rencana merupakan pengembangan lebih lanjut dari theory of reasoned action (TRA). Sedangkan munculnya niat untuk berperilaku ditentukan oleh tiga faktor, yaitu:

1. Behavioral beliefs merupakan keyakinan individu akan hasil dari suatu perilaku dan evaluasi atas hasil tersebut.

2. Normative beliefs merupakan keyakinan tentang harapan normatif orang lain dan motivasi untuk memenuhi harapan tersebut.

3. Control beliefs merupakan keyakinan tentang keberadaan hal-hal yang mendukung atau menghambat perilaku yang akan ditampilkan dan persepsinya tentang seberapa kuat hal-hal yang mendukung dan menghambat perilakunya tersebut (perceived power).

\subsection{Teori Pembelajaran Sosial}

Teori belajar sosial dikenalkan oleh Bandura pada tahun 1986. Konsep dari teori ini menekankan pada komponen kognitif dari pikiran, pemahaman dan evaluasi. Bandura (1986) mengatakan bahwa faktor sosial dan kognitif serta faktor pelaku memainkan peran penting dalam pembelajaran. Faktor kognitif berupa ekspektasi/penerimaan untuk meraih keberhasilan, sedangkan faktor sosial mencakup pengamatan. Teori ini merupakan perluasan teori pengkondisian operan dari Skinner yaitu teori yang mengandaikan perilaku sebagai suatu fungsi dari konsekuensikonsekuensinya.

Jatmiko (2006) menjelaskan bahwa teori pembelajaran sosial ini relevan untuk menjelaskan perilaku wajib pajak dalam memenuhi kewajibannya membayar pajak. Seseorang akan taat membayar pajak tepat pada waktunya, jika lewat pengamatan dan pengalaman langsungnya, hasil pungutan pajak itu telah memberikan kontribusi nyata pada pembangunan di wilayahnya. Seseorang juga akan taat membayar pajak knya. Terkait dengan proses penguatan, proses tersebut cukup relevan apabila dihubungkan dengan pengaruh sanksi pajak terhadap kepatuhan wajib pajak.

\subsection{Kepatuhan Wajib Pajak}

Peningkatan Pendapatan Asli Daerah khususnya dari penerimaan pajak sangat didominasi dari kesadaran warga negara. Apabila wajib pajak dapat memenuhi kewajiban dan hak perpajakannya maka mereka dapat dikatakan patuh terhadap peraturan perpajakan (Crhistina dan Kepramareni, 2012).

Kepatuhan wajib pajak dikemukakan oleh Norma D. Nowak (moh. Zain: 2004) menjelaskan bahwa: "sebagai suatu iklim kepatuhan dan kesadaran pemenuhan kewajiban perpajakan, tercermin dalam situasi di mana:

1. Wajib pajak paham atau berusaha memahami semua ketentuan peraturan perundang-undangan perpajakan

2. Mengisi formulir pajak dengan lengkap dan jelas

3. Menghitung jumlah pajak yang terutan dengan benar 
Jurnal Progres Ekonomi Pembangunan (JPEP)

Volume 5, Nomor 1, Tahun 2020

Page: $71-82$

http://ojs.uho.ac.id/index.php/JPEP

4. Membayar pajak yang teruang dengan benar

5. Membayar pajak yang terutang tepat waktunya

Safri Nurmantu (2010) menjelasakan bahwa kepatuhan pepajakan dapat didefinisikan sebagai suatu keadaan di mana wajib pajak memenuhi semua kewajiban perpajakan dan melaksanakan hak perpajakannya.

Gunadi (2013: 94) pengertian kepatuhan pajak adalah: dalam hal ini diartikan bahwa wajib pajak mempunyai kesediaan untuk memenuhi kewajiban perpajakannya sesuai dengan aturan yang berlaku tanpa perlu diadakan permeriksaan, invesigasi seksama, peringatan ataupun ancaman dan penerapan sanksi hukum maupun administrasi.

\subsection{Kesadaran Wajib Pajak}

Kesadaran merupakan unsur dalam diri manusia untuk memahami realitas dan bagaimana mereka bertindak atau bersikap terhadap realitas. Jatmiko (2006) menjelaskan bahwa kesadaran adalah keadaan mengetahui atau mengerti. Nurlis (2010) menguraikan beberapa bentuk kesadaran membayar pajak yang mendorong wajib pajak untuk membayar pajak yakni:

1. Kesadaran bahwa pajak merupakan bentuk partisipasi dalam menunjang pembangunan negara. Dengan menyadari hal ini, wajib pajak mau membayar pajak karena merasa tidak dirugikan dari pemungutan pajak yang dilakukan.

2. Kesadaran bahwa penundaan pembayaran pajak dan pengurangan beban pajak sangat merugikan negara. Wajib pajak mau membayar pajak karena memahami bahwa penundaan pembayaran pajak dan pengurangan beban pajak berdampak pada kurangnya sumber daya finansial yang dapat mengakibatkan terhambatnya pembangunan negara.

3. Kesadaran bahwa pajak ditetapkan dengan Undang-undang dan dapat dipaksakan. Wajib pajak akan membayar karena pembayaran pajak disadari memiliki landasan hukum yang kuat dan merupakan kewajiban mutlak setiap warga negara. Jatmiko (2006) dan Sumarso (1998) menyatakan bahwa kesadaran perpajakan masyarakat yang rendah seringkali menjadi salah satu sebab banyaknya potensi pajak yang tidak dapat dijaring.

\subsection{Akuntabilitas Pelayanan Publik}

Konteks pelayanan publik maka akuntabilitas berarti suatu ukuran yang menunjukkan seberapa besar tingkat kesesuaian penyelenggaraan pelayanan dengan ukuran nilai-nilai atau norma eksternal yang ada di masyarakat atau yang dimiliki oleh para stakeholder. Dengan demikian tolak ukur dalam akuntabilitas pelayanan publik adalah publik itu sendiri yaitu arti nilai-nilai atau normanorma yang diakui, berlaku dan berkembang dalam kehidupan publik. Nilai-nilai atau norma tersebut diantaranya transparansi pelayanan, prinsip keadilan, jaminan penegakan hukum, hak asasi manusia, orientasi pelayanan yang dikembangkan terhadap masyarakat pengguna jasa. Agar nilainilai atau norma itu dapat terus terlaksana diperlukan suatu kontrol dari masyarakat Dwiyanto (2002:10). Berdasarkan keputusan Menteri Pendayagunaan Aparatur Negara Nomor KEP/26/M.PAN/2/2004 Tanggal 24 Februari 2004 tentang Teknik Transparansi dan Akuntabilitas Penyelenggaraan Pelayanan Publik, penyelenggaraan pelayanan publik harus dapat dipertanggungjawabkan, baik kepada publik maupun kepada atasan/pimpinan unit pelayanan instansi pemerintah sesuai dengan ketentuan peraturan perundang-undangan.

\subsection{Kerangka Konsep}

Berdasarkan landasan teori dan penelitian-penelitian terdahulu yang telah dikemukakan sebelumnya, maka kerangka konseptual dikemukakan sebagai berikut: 
Jurnal Progres Ekonomi Pembangunan (JPEP)

Volume 5, Nomor 1, Tahun 2020

Page: $71-82$

http://ojs.uho.ac.id/index.php/JPEP

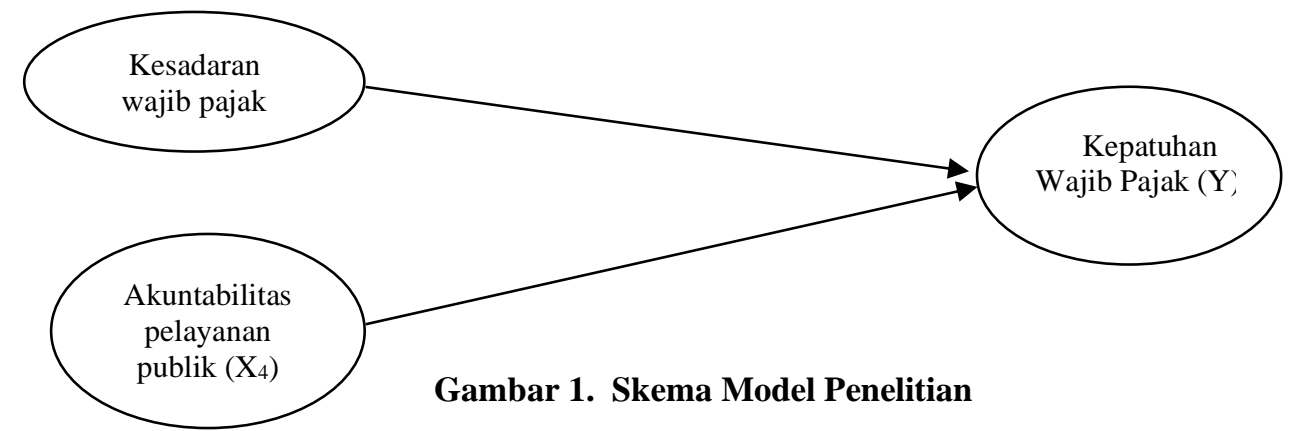

\subsection{Hipotesis}

1. Kesadaran Wajib Pajak berpengaruh positif dan signifikan terhadap Kepatuhan Wajib Pajak Kendaraan Bermotor Samsat kota Kendari

2. Akuntabilitas Pelayanan Publik Berpengaruh positif dan signifikan Terhadap Kepatuhan Wajib Pajak

\section{METODE PENELITIAN}

Populasi dalam penelitian ini adalah seluruh wajib pajak kendaraan bermotor melalui kantor UPTD Samsat kota wilayah kota kendari tahun anggaran 2017 yaitu sebesr $11 \quad .0$ Wajib Pajak. Dan sampel dalam penelitian ini dilakukan dengan menggunakan teknik pengaml _ i sampel secara kebetulan (accidental sampling) dimana penentuan anggota sampel diambil berdasarkan tidak direncanakan terlebih dahulu tetapi didapatkan atau dijumpai secara tiba-tiba. Penentuan sampel dilakuakukan dengan menggunaka rumus Slovin. Sehingga besarnya sampel sebanyak 90 responden. Analisis yang digunakan adalah regresi linear berganda

\section{HASIL DAN PEMBAHASAN \\ 4.1. Hasil Penelitian \\ 4.1.1. Karakteristik Responden}

Identitas atau karakteristik pribadi merupakan data yang penting dicermati dahulu, karena faktor yang mudah didefinisikan dan mudah didapatkan begitu juga obyektivitasnya. Identitas responden perlu diketahui karena turut menentukan kevalidan penelitian. Penggambaran responden penelitian ini menggunakan analisis deskriptif, dimana penggambaran dilakukan apa adanya.

1. Karakteristik Responden Berdasarkan Jenis Kelamin

Responden berdasarkan jenis kelamin sesuai data yang diperoleh menunjukkan bahwa responden berjenis kelamin laki-laki sebanyak 83 orang $(92.23 \%)$ dan berjenis kelamin perempuan sebanyak 7 orang $(7.77 \%)$.

2. Karakteristik Responden Berdasarkan Umur

Dilihat dari usia responden dalam penelitian ini dapat menunjukkan bahwa responden dari pegawai pada Unit Pelaksana Teknis Dinas Samsat Wilayah Kota Kendari ini, dilihat dari tingkat umur adalah sebanyak 14 orang (15.56\%) berumur 25-29 tahun, sebanyak 34 orang $(37,78 \%)$ berumur 30-34 tahun, sebanyak 34 orang (37.78\%) berumur 35-39 tahun, dan sebanyak 13 orang $(14.44 \%)$ berumur lebih besar dari 40 tahun.

\section{Karakteristik Responden Berdasarkan Pendidikan}

Sedangkan untuk kondisi responden dilihat dari pendidikan, maka dapat dijelaskan bahwa kondisi responden pada Unit Pelaksana Teknis Dinas Samsat Wilayah Kota Kendari adalah 20 orang (22.22\%) SLTA, 15 orang (16.67\%) Diploma, 43 orang (47.78\%) S1, dan 12 orang (13.33\%) berpendidikan Pascasarjana. 
Jurnal Progres Ekonomi Pembangunan (JPEP)

Volume 5, Nomor 1, Tahun 2020

Page: $71-82$

http://ojs.uho.ac.id/index.php/JPEP

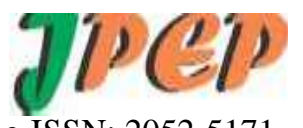

e-ISSN: 2052-5171

\subsubsection{Perkembangan Jumlah Kendaraan Bermotor dan Realisasi Pajak}

Sesuai hasil penelitian, perkembangan jumlah kendaraan bermotor pada Unit Pelaksana Teknis Dinas Pendapatan dan Asset Daerah Provinsi Sulawesi Tenggara ditampilkan melalui Tabel 5.1 .

Tabel 1

Daftar Jumlah Kendaraan Roda Dua Dan Roda Empat, Pendaftaran Ulang, Kendaraan Baru, Mutasi Masuk Tahun 2016-2018

\begin{tabular}{|c|c|c|c|c|c|c|c|c|c|c|c|c|c|c|c|c|c|}
\hline \multirow{3}{*}{ No } & \multirow{3}{*}{ Tahun } & \multicolumn{5}{|c|}{ Pendaftaran Ulang } & \multicolumn{5}{|c|}{ Kendaraan Baru } & \multicolumn{5}{|c|}{ Mutasi Masuk } & \multirow{3}{*}{$\begin{array}{c}\text { Jumlah } \\
\text { Unit }\end{array}$} \\
\hline & & \multicolumn{2}{|c|}{ Roda 2} & \multicolumn{3}{|c|}{ Roda 4} & \multicolumn{2}{|c|}{ Roda 2} & \multicolumn{3}{|c|}{ Roda 4} & \multicolumn{2}{|c|}{\begin{tabular}{|l|} 
Roda 2 \\
\end{tabular}} & \multicolumn{3}{|c|}{ Roda 4} & \\
\hline & & $\mathbf{M}$ & $\mathbf{H}$ & $\mathbf{M}$ & $\mathbf{K}$ & $\mathbf{H}$ & $\mathbf{M}$ & $\mathbf{H}$ & $\mathbf{M}$ & $\mathbf{K}$ & $\mathbf{H}$ & $\mathbf{M}$ & $\mathbf{H}$ & $\mathbf{M}$ & $\mathbf{K}$ & $\mathbf{H}$ & \\
\hline 1 & 2 & 3 & 4 & 5 & 6 & 7 & 8 & 9 & 10 & 11 & 12 & 13 & 14 & 15 & 16 & 17 & 18 \\
\hline 1 & 2016 & 294 & 2.210 & 75 & 174 & 433 & 100 & 2.220 & 43 & 10 & 138 & 0 & 62 & 4 & 0 & 66 & 5.829 \\
\hline 2 & 2017 & 2.650 & 30.931 & 927 & 1.710 & 6.912 & 1.037 & 25.366 & 266 & 99 & 1.592 & 2 & 703 & 9 & 26 & 927 & 73.157 \\
\hline 3 & 2018 & 2.346 & 34.577 & 933 & 1.545 & 7.599 & 1.023 & 27.235 & 158 & 143 & 2.303 & 195 & 469 & 0 & 27 & 673 & 79.226 \\
\hline
\end{tabular}

Sumber : UPTD Samsat Kota Kendari

Tabel 1 menunjukkan bahwa jumlah kendaraan mengalami peningkatan selama 3 tahun terakhir. Dimana pada tahun 2016 sebanyak 5.829 unit. Tahun 2017 sebanyak 73.157 unit dan pada tahun 2018 mencapai 79.226 unit.

\subsection{Deskripsi Variabel}

Unit Pelaksana Teknis Dinas Samsat dalam menjalankan tugas dan fungsinya sebagai salah satu unit yang berperan penting dalam penerimaan pendapatan asli daerah melalui penerimaan pajak. Salah satu penerimaan daerah bersumber dari penerimaan pajak yakni pajak kendaraan bermotor. Untuk mengetahui lebih jauh berkaitan dengan pajak kendaraan bermotor perlu dijabarkan sebagai berikut:

\subsubsection{Kesadaran Wajib Pajak}

Kesadaran wajib pajak adalah kemauan wajib pajak dalam memenuhi kewajibannya dalam membantu menggerakan roda pembangunan yang dibangun pemerintah melalui Kepala Unit Pelaksana Teknis Samsat Kota Kendari dalam memberikan pelayanan yang masksimal dalam mencapai tujuan pembangunan daerah yang dapat diamati dari dimensi undang-undang dan sanksi dalam peraturan perpajakan, sadar bahwa membayar pajak adalah suatu kewajiban, dan persepsi wajib pajak tentang pelaksanaan sanksi denda PPh. Sesuai hasil penelitian, maka secara deskriptif item pernyataan yang berkaitan dengan kesadaran wajib pajak. Menunjukkan bahwa rata-rata skor variabel kesadaran wajib pajak adalah sangat baik $(4,16)$. Nilai skor rata-rata yang dicapai tersebut berada pada kategori sangat baik (interval skor 4,10 - 4,2). Ini berarti bahwa kesadaran wajib pajak berada pada kondisi penilaian sangat baik bila diamati dari indikator undang-undang dan sanksi dalam peraturan perpajakan, kesadaran bahwa membayar pajak adalah suatu kewajiban, dan persepsi wajib pajak tentang pelaksanaan sanksi denda $\mathrm{PPh}$.

\subsubsection{Akuntabilitas Pelayanan Publik}

Akuntabilitas pelayanan publik menunjukkan bahwa untuk mengukur kualitas pelayanan publik maka dapat diamati dari lima indikator yaitu tangibles adalah banunan fisik, ruang tunggu dan perlengkapan kantor, realibility adalah pelayanan yang sesuai, bertindak cepat dan teliti, responsiveness adalah sigap dalam melayani serta tanggap terhadap keinginan masyarakat, assurance adalah memiliki pengetahuan, bersikap ramah, sopan dalam memberikan pelayanan dan jaminan keamanan dan emphaty adalah perhatian secara individual serta kemudahan melakukan akses informasi. Sesuai hasil penelitian, maka secara deskriptif item pernyataan yang berkaitan dengan kesadaran wajib pajak menunjukkan bahwa rata-rata skor variabel Akuntabilitas Pelayanan Publik adalah 4,20. Nilai skor rata-rata yang dicapai tersebut berada pada kategori sangat baik (interval skor 4,00-4,60). Ini berarti bahwa Akuntabilitas Pelayanan Publik berada pada kondisi 
Jurnal Progres Ekonomi Pembangunan (JPEP)

Volume 5, Nomor 1, Tahun 2020

Page: $71-82$

http://ojs.uho.ac.id/index.php/JPEP

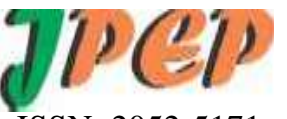

e-ISSN: 2052-5171

penilaian sangat baik bila diamati dari indikator bukti fisik, keandalan, daya tanggap, jaminan dan empati oleh masyarakat yang dilayani selama proses pembayaran pajak.

\subsubsection{Kepatuhan Wajib Pajak}

Kepatuhan wajib pajak adalah kewajiban wajib pajak dalam memenuhi kwajibannya atas pendapatan maupun asset yang dimiliki oleh wajib pajak. Kepatuhan dalam penelitian ini dikaji melalui dimensi kepatuhan formal dan kepatuhan meteril. Sesuai hasil penelitian, maka secara deskriptif item pernyataan yang berkaitan dengan kesadaran wajib pajak menunjukkan bahwa ratarata skor variabel kepatuhan wajib pajak adalah 4,15. Nilai skor rata-rata yang dicapai tersebut berada pada kategori sangat baik (interval skor 4,04 - 4,27). Ini berarti bahwa kepatuhan wajib pajak berada pada kondisi penilaian baik bila diamati dari dimensi kepatuhan formal dan kepatuhan materi oleh petugas dalam memberikan pelayanan kepada masyarakat dalam proses pembayaran pajak di UPTD Samsat Kota kendari.

\subsection{Pengujian Validitas dan Reliabilitas \\ 1. Uji Validitas}

Validitas adalah ukuran yang menunjukkan sejauhmana instrumen pengukur mampu mengukur apa yang diukur. Dalam konteks penelitian ini, uji validitas dimaksudkan untuk mengukur sejauhmana kuesioner yang disiapkan mampu mengukur variabel, Kesadaran Wajib Pajak (X $\mathrm{X}_{1}$ ), Akuntabilitas Pelayanan Publik (X2), dan Kepatuhan Wajib Pajak (Y) kendaraan bermotor melalui kantor UPTD Samsat Kota Kendari provinsi Sulawesi Tenggara.

Sesuai data dimaksud maka diketahui bahwa koefisien korelasi untuk variabel pengetahuan wajib pajak dengan skor untuk masing-masing total pernyataan adalah signifikan atau valid secara statistik. Hasil uji validitas pada variabel pengetahuan menunjukkan bahwa item pernyataan yang diajukan sebanyak 8 pernyataan pada variabel pengetahuan wajib pajak adalah valid karena nilai probabilitasnya lebih kecil dari $0,05(\mathrm{p}<0,05)$ dan semua item indikator berkorelasi positif dengan variabel pengetahuan wajib pajak yang ditandai dengan nilai pearson correlation yaitu $\geq 0,30$.

\section{Uji Reliabilitas}

Pengujian reliabitas adalah alat ukur untuk mengukur suatu kuesiner yang merupakan indikator dari variabel atau konstruk. Apabila suatu alat pengukur telah dikatakan valid, maka tahap berikutnya adalah mengukur reliabilitas dari alat. Reliabilitas adalah ukuran yang menunjukkan konsistensi dari alat ukur dalam mengukur gejala yang sama di lain kesempatan

Berdasarkan data terlampir maka uji reliabilitas dilakukan dengan menggunakan program aplikasi SPSS versi 18.0 dan diperoleh Berdasarkan hasil uji reliabilitas instrumen kesadaran wajib pajak, pengetahuan wajib pajak, Sanksi Perpajakan, akuntabilitas layanan pajak, maka diketahui bahwa instrumen tersebut adalah reliabel. Menunjukkan bahwa nilai cronbach's alpha setiap item indikator dari variabel kesadaran wajib pajak adalah signifikan karena lebih besar dari 0,6 $(\alpha>0,6)$ sehingga dapat dikatakan bahwa masing-masing item pernyataan reliabel.

\subsubsection{Uji Hipotesis}

Sesuai dengan tujuan dan hipotesis penelitian, maka pembuktian hipotesis dilakukan dengan

\section{Koefisien Korelasi dan Determinasi $\left(\mathbf{R}^{2}\right)$}

Koefisien korelasi berganda untuk variabel kesadaran wajib pajak $\left(\mathrm{X}_{1}\right)$, akuntabilitas pelayanan publik $(\mathrm{X} 2)$ dan kepatuhan wajib pajak $(\mathrm{Y})$ sebesar $(\mathrm{R})=0,852$. Dengan demikian, keempat variabel secara bersama-sama (simulthan), mempunyai hubungan yang kuat. Koefisien determinasi $(\mathrm{R}$ square $)=0.726$ atau 72,6\%. Dengan demikian, maka kontribusi (sumbangan) variabel yang mempengaruhi kepatuhan wajib pajak kendaraan bermotor melalui kantor UPTD 
Jurnal Progres Ekonomi Pembangunan (JPEP)

Volume 5, Nomor 1, Tahun 2020

Page: $71-82$

http://ojs.uho.ac.id/index.php/JPEP

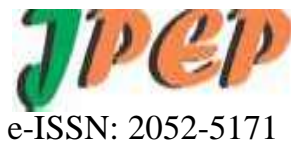

Samsat Kota Kendari provinsi Sulawesi Tenggara sebesar $72,60 \%$, sedangkan sisanya $(27,40 \%)$ dipengaruhi oleh variabel lain yang tidak masuk dalam analisis.

\section{Uji F (Simulthan)}

Pengaruh kesadaran wajib pajak $\left(\mathrm{X}_{1}\right)$, akuntabilitas pelayanan publik $\left(\mathrm{X}_{2}\right)$ secara bersamasama berpengaruh terhadap kepatuhan wajib pajak (Y) kendaraan bermotor melalui kantor UPTD Samsat Kota Kendari provinsi Sulawesi Tenggara, sebesar F hitung 13.855 dengan taraf signifikansi $0,000<\alpha=0,05$. Hal ini ditunjukkan bahwa semakin baik kesadaran wajib pajak, pengetahuan pajak, sanksi pajak, dan akuntabilitas pelayanan publik maka kepatuhan wajib pajak semakin baik.

\section{Uji t (Parsial)}

Sesuai dengan hasil analisis yang terdapat pada (Lampiran 5) menunjukkan bahwa :

a. Variabel wajib Pajak $\left(\mathrm{X}_{1}\right)$ secara parsial belum berpengaruh secara signifikan terhadap kepatuhan wajib pajak kendaraan bermotor melalui kantor UPTD Samsat Kota Kendari provinsi Sulawesi Tenggara. Hal ini ditunjukkan oleh hasil uji t pada tingkat sigf. 0,000< $\alpha=0,05$.

b. Variabel Akuntabilitas Pelayanan Pajak (X2) secara parsial belum berpengaruh secara signifikan terhadap kepatuhan wajib pajak kendaraan bermotor melalui kantor UPTD Samsat Kota Kendari provinsi Sulawesi Tenggara. Hal ini ditunjukkan oleh hasil uji t pada tingkat sigf. $0.040<\alpha=0,05$.

\section{Hasil Analisis Regresi Linier Berganda}

Langkah untuk mengetahui kesadaran wajib pajak $\left(\mathrm{X}_{1}\right)$, akuntabilitas pelayanan publik (X2) terhadap kepatuhan wajib pajak (Y) kendaraan bermotor melalui kantor UPTD Samsat Kota Kendari Provinsi Sulawesi Tenggara, yakni melalui analisis regresi linier berganda. Data hasil analisis kemudian direkapitulasi sebagaimana ditampilkan pada Tabel 2 :

Tabel 2

\section{Hasil Analisis Regresi}

\begin{tabular}{|l|l|c|c|}
\hline \multicolumn{1}{|c|}{ Variabel } & \multicolumn{1}{|c|}{$\begin{array}{c}\text { Koefisien } \\
\text { Regresi }(\mathrm{b})\end{array}$} & $\begin{array}{c}\mathrm{T}_{\text {hitung }} \\
(\mathrm{db}=85)\end{array}$ & $\begin{array}{c}\text { Probabilitas } \\
\text { Parsial }(\mathrm{P})\end{array}$ \\
\hline Kesadaran Wajib Pajak $\left(\mathrm{X}_{1}\right)$ & $=.601$ & 4.824 & 0.000 \\
Akuntabilitas Pelayanan Publik (X2) & $=.310$ & 2.074 & 0.040 \\
\hline Constanta (a) & $=14.212$ & \\
Korelasi (R) & $=0,852$ & & \\
Koefisien Determinansi (R Square) & $=0,726$ & & \\
F $_{\text {hitung }}$ & $=13.855$ & & \\
Probabilitas simulthan & $=.000$ & & \\
\hline
\end{tabular}

Sumber : Lampiran 5 (Diolah)

Berdasarkan Tabel 2 di atas, maka diperoleh persamaan regresi linier berganda sebagai berikut :

$$
\mathrm{Y}=13,855+0.601 \mathrm{X}_{1}+0.310 \mathrm{X}_{2}
$$

Persamaan regresi linier tersebut dapat diinterpretasikan ;

1. Nilai konstanta (a) sebesar 13,855 . Hal ini menunjukkan bahwa jika terjadi perubahan terhadap kepatuhan wajib pajak, maka akan terjadi perubahan terhadap kepatuhan wajib pajak, dimana variable Kesadaran wajib pajak $\left(\mathrm{X}_{1}\right)$, Akuntabilitas pelayanan publik (X2) diasumsi konstan

2. Nilai koefisien regresi $\left(\mathrm{X}_{1}\right)$ sebesar 0.601 . Hal ini menunjukkan bahwa jika terjadi perubahan Kesadaran wajib, maka akan terjadi perubahan terhadap Kesadaran wajib pajak $\left(\mathrm{X}_{1}\right)$ sebesar 0.089 kali, dimana variable Akuntabilitas pelayanan publik (X2) diasumsi konstan.

3. Nilai koefisien regresi (X2) sebesar 0.310, ini menunjukkan bahwa jika terjadi perubahan terhadap Akuntabilitas pelayanan publik, maka akan terjadi perubahan akuntabilitas pelayanan 
Jurnal Progres Ekonomi Pembangunan (JPEP)

Volume 5, Nomor 1, Tahun 2020

Page: $71-82$

http://ojs.uho.ac.id/index.php/JPEP

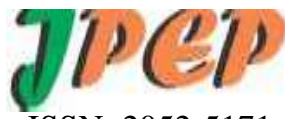

e-ISSN: 2052-5171

pajak pajak (X2) sebesar -0.059 kali, dimana variable Kesadaran wajib pajak $\left(\mathrm{X}_{1}\right)$ diasumsi konstan

4. Koefisien korelasi antara kesadaran wajib pajak, dan akuntabilitas pelayanan pajak terhadap kepatuhan pajak kendaraan bermotor pada UPTD Samsat Kota kendari sebesar 0.852 berarti terdapat hubungan yang kuat dan positif. Artinya bahwa apabila kesadaran wajib pajak yang dibarengi dengan kepatuhan serta pengetahuan yang didukung dengan akuntabilitas pelayanan, maka kepatuhan wajib pajak akan baik.

5. koefisien determinasi yang diperoleh sebesar 0,726 , ini berarti bahwa variasi baiknya kesadaran, akuntabilitas terhadap kepatuhan pajak kendaraan bermotor pada Unit Pelaksana Teknis Dinas Samsat Kota Kendari berpengaruh terhadap kepatuhan pajak sebesar 72,40. Selebihnya yaitu sebesar 27,60 dipengaruhi oleh faktor lain yang tidak dimasukkan kedalam model penelitian ini

\subsection{Pembahasan}

Pada bagian ini dibahas hasil-hasil yang diperoleh dalam penelitian ini. Masalah utama dalam penelitian ini adalah untuk mengetahui pengaruh Kesadaran wajib pajak $\left(\mathrm{X}_{1}\right)$, Akuntabilitas Pelayanan Publik (X2) berpengaruh signifikan terhadap Kepatuhan Wajib pajak pada Unit Pelaksana Teknis Dinas Samsat Kota Kendari Provinsi Sulawesi Tenggara. Masalah tersebut dapat dibagi dalam beberapa kelompok masalah yaitu :

\subsubsection{Pengeruh Kesadaran Wajib Pajak Terhadap Kepatuhan}

Kesadaran wajib pajak berkonsekuensi logis untuk wajib pajak, yaitu kerelaan wajib pajak memberikan kontribusi dana ntuk pelaksaan fungsi perpajakan dengan cara membayar pajak tepat waktu dan tepat jumlah (Tjiptohadi, 2005). Wajib Pajak yang memiliki kesadaran tinggi tidak menganggap membayar pajak merupakan suatu beban namun mereka menganggap hal ini adalah suatu kewajiban dan tanggung jawab mereka sebagai warga Negara sehingga mereka tidak keberatan dan membayar pajaknya dengan suka rela (Yusnidar, 2015). Kesadaran wajib pajak sangat diperlukan mengenai fungsi perpajakan yaitu sebagai pembiayaan negara agar kepatuhan wajib pajak dapat ditingkatkan (Jatmiko, 2006).

Hasil penelitian yang diperoleh bahwa kesadaran wajib pajak memberikan pengaruh yang signifikan terhadap kepatuhan wajib pajak. Hal ini ditunjukkan oleh hasil uji t pada tingkat kepercayaan 0,95 atau taraf nyata $\alpha=0,05$ atau dengan nilai probabilitas $=0,000<0,05$. Hal ini diduga disebabkan akibat pesatnya kemajuan teknologi yang berkembang sementara wajib pajak masih banyak merevisi obyek pajak sehingga kecenderungan untuk berurusan dengan pajak membutuhkan waktu dan tenaga ekstra bagi wajib pajak tersebut. Hal ini disadari oleh wajib pajak dimana pajak sebagai penyumbang terbesar dari penerimaan negara, memiliki pengaruh yang sangat besar terhadap keberlangsungan pembangunan sebuah negara meskipun terdapat sektor sektor lainnya yang juga berkontribusi pada penerimaan sebuah negara. Terdapat dua fungsi pokok pajak yaitu fungsi anggaran atau budgetair dan fungsi mengatur atau regulerend. Bagi pemerintah pajak dalam aspek anggaran digunakan dalam membiayai keperluan pemerintah, dan dalam aspek mengatur atau regulerend adalah sebagai alat untuk mengendalikan dan melangsungkan kebijakan pemerintah dalam bidang sosial dan ekonomi (Mardiasmo, 2016:4).

Undang-Undang telah mengatur ketentuan umum dan tatacara peraturan perpajakan, tak terkecuali mengenai sanksi perpajakan. Harus ada sanksi perpajakan bagi wajib pajak agar wajib pajak mematuhi peraturan perpajakan (Fuadi dan Mangoting, 2013). Wajib pajak berpendapat bahwa apabila sanksi perpajakannya akan lebih banyak merugikannya maka wajib pajak akan memenuhi kewajibannya (Jatmiko, 2006). Ali et al (2001) dalam penelitiannya menyatakan bahwa dengan adanya audit dan sanksi dapat mencegah ketidakpatuhan. 
Jurnal Progres Ekonomi Pembangunan (JPEP)

Volume 5, Nomor 1, Tahun 2020

Page: $71-82$

http://ojs.uho.ac.id/index.php/JPEP

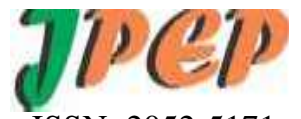

e-ISSN: 2052-5171

\subsubsection{Pengaruh Akuntabilitas Pelayanan Publik Terhadap Kepatuhan}

Untuk mencapai akuntabilitas bagi penerima pelayanan wajib pajak, maka dituntut kualitas pelayanan yang tercermin dari transparansi, akuntabilitas, kondisional, partisipatif, kesamaan hak, dan keseimbangan hak dan kewajiban. Pada hakekatnya, kualitas pelayanan public dapat diketahui dengan cara membandingkan persepsi para wajib pajak atas layanan yang sesungguhnya mereka inginkan. Apabila pelayanan dalam prakteknya yang diterima oleh wajib pajak sama dengan harapan atau keinginan mereka, maka wajib pajak tersebut dikatakan sudah memuaskan atau sudah berkualitas.

Dua faktor utama yang mempengaruhi kualitas layanan, yaitu pelayanan yang diharapkan dan pelayanan yang diterima (Rakhmat. 2009). Sementara itu, Moenir (2008) menyebutkan enam bahwa ada enam factor yang penting guna terwujudnya pelayanan yang efektif yakni (a) kesadaran, (b) aturan, (c) organisasi, (d) pendapatan, (e) kemampuan dan ketrampilan, dan (f) sarana pelayanan.

Berdasarkan hasil penelitian dan analisis yang dilakukan berkaitan dengan akuntabilitas pelayanan public terhadap kepatuhan wajib pajak kendaraan bermotor melalui kantor Samsat Kota kendari diperoleh hasil bahwa akuntabilitas pelayanan publik tidak berpengaruh signifikan terhadap kepatuhan wajib pajak dalam membayar pajak. Hal ini ditunjukkan oleh hasil uji t pada tingkat kepercayaan 0,95 atau taraf nyata $\alpha=0,05$ atau dengan nilai probabilitas $=0,040<0,05$. Hal ini diduga disebabkan akibat kurangnya kesadaran pemilik kendaraan bermotor dalam memenuhi kewajiban serta tanggungjawab dalam membayar pajak yang dipengaruhi oleh tingkat pendapatan pemilik kendaraan bermotor tersebut. Sementara itu, pelayanan yang diberikan oleh petugas telah memenuhi standar seperti bukti fisik, keandalan, daya tanggap, jaminan, dan empati.

\subsubsection{Pengaruh Kesadaran, Pengetahuan, Sanksi dan Akuntabilitas Terhadap Kepatuhan Wajib pajak}

Kepatuhan wajib pajak adalah wajib pajak orang pribadi mempunyai kesediaan untuk memenuhi kewajiban pajaknya sesuai dengan aturan yang berlaku tanpa perlu diadakannya pemeriksaan, investigasi seksama, peringatan, ataupun ancaman dan penerapan sanksi baik hukum maupun administrasi Gunadi, 2005). Lebih lanjut dikatakan oleh Nurmantu (2005) yakni kepatuhan wajib pajak adalah kondisi dimana wajib pajak memenuhi semua kewajiban perpajakannya dan melaksanakan hak perpajakannya. Keputusan Menteri Keuangan No. 505/KMK.04/2000, bahwa kriteria kepatuhan wajib pajak adalah:

a. Tepat waktu dalam menyampaikan SPT untuk semua jenis pajak dalam 2 tahun terakhir.

b. Tidak mempunyai tunggakan pajak untuk semua jenis pajak, kecuali telah memperoleh izin untuk mengangsur atau menunda pembayaran pajak.

c. Tidak pernah dijatuhi hukuman karena melakukan tindak pindana di bidang perpajakan dalam waktu 10 tahun terakhir.

d. Dalam 2 tahun terakhir menyelenggarakan pembukuan dan dalam hal terhadap wajib pajak pernah dilakukan pemeriksaan, koreksi pada pemeriksaan yang terakhir untuk masing-masing pajak yang terutang paling banyak $5 \%$.

e. Wajib pajak yang laporan keuangan untuk 2 tahun terakhir di audit oleh akuntan public dengan pendapat wajar tanpa pengecualian, atau pendapat dengan pengecualian sepanjang tidak mempengaruhi laba rugi fiscal.

Hasil penelitian menunjukkan bahwa faktor kesadaran wajib pajak $\left(\mathrm{X}_{1}\right)$, pengetahuan pajak $\left(\mathrm{X}_{2}\right)$, sanksi pajak $\left(\mathrm{X}_{3}\right)$, akuntabilitas pelayanan publik $\left(\mathrm{X}_{4}\right)$ secara simultan berpengaruh signifikan terhadap Kepatuhan wajib pajak (Y) pada Unit Pelaksana Teknis Dinas Samsat Kota Kendari. Hal diduga beberapa factor seperti factor pendidikan, pendapatan, serta sosialisasi dari pemerintah terhadap wajib pajak perlu ditingkatkan guna mendorong pertumbuhan ekonomi daerah melalui pajak. Hal ini sejalan dengan yang dikemukakan oleh Rahayu (2010) bahwa Faktor-faktor yang mempengaruhi kepatuhan wajib pajak dalam membayar pajak yaitu: 
Jurnal Progres Ekonomi Pembangunan (JPEP)

Volume 5, Nomor 1, Tahun 2020

Page: $71-82$

http://ojs.uho.ac.id/index.php/JPEP

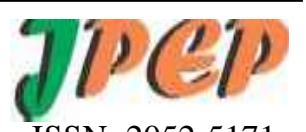

e-ISSN: 2052-5171

1. Faktor pendidikan wajib pajak, yang meliputi pendidikan formal dan pengetahuan wajib pajak.

2. Faktor pendapatan wajib pajak, yang meliputi besarnya pendapatan bersih wajib pajak dari pekerjaan pokok dan sampingannya, serta jumlah anggota keluarga yang masih har "biayai.

3. Faktor pelayanan aparatur pajak, disaat pelayanan penyampaian informasi, ayanan pembayaran, maupun pelayanan keberatan dan penyaranan

4. Faktor penegakan hukum pajak, yang terdiri dari saksi-saksi, keadilan dalam penentuan jumlah pajak yang dipungut, pengawasan dan pemeriksaan.

5. Faktor sosialisasi, diantaranya pelaksanaan sosialisasi dan media sosialisasi.

\section{KESIMPULAN}

Berdasarkan permasalahan, tujuan, hasil analisa dan pembahasan dalam penelitian ini, maka dapat ditarik beberapa kesimpulan sebagai berikut:

1. Kesadaran wajib pajak, Pengetahuan pajak, Sanksi perpajakan, Akuntabilitas pelayanan publik secara bersama-sama berpengaruh terhadap kepatuhan wajib pajak kendaraan bermotor pada kantor Samsat Kota Kendari Provinsi Sulawesi Tenggara, Dengan kata lain bahwa Kesadaran, Pengetahuan, Sanksi, dan Akuntabilitas semakin baik sehingga masyarakat memenuhi kewajibannya guna mematuhi kewajibannya dalam membayar pajak kendaraan.

2. Kesadaran wajib pajak secara parsial berpengaruh terhadap kepatuhan wajib pajak kendaraan bermotor pada kantor samsat Kota Kendari, hal ini ditunjukkan semakin tinggi kesadaran wajib pajak maka semakin bayak yang membayar pajak tepat waktu.

3. Akuntabilitas pelayanan publik secara parsial berpengaruh terhadap kepatuhan wajib pajak kendaraan bermotor pada kantor samsat Kota Kendari, hal ini ditunjukkan dengan adanya transparansi pembayaran pajak yang dilakukan Samsat dalam memberikan pelayanan prima.

\section{DAFTAR PUSTAKA}

Ajzen, Icek, 1988. from intentions to actions: attitudes, personality, \& behavior. Chicago: Dorsey Press.

Abdul Rahman. (2010). Panduan Pelaksanaan Administrasi Pajak: Untuk Karyawan, Pelaku Bisnis Dan Perusahaan. Bandung: Nuansa.

Arum, Harjanti Puspa. 2012. "Pengaruh Kesadaran Wajib Pajak, Pelayanan Fiskus, dan Sanksi Pajak Terhadap Kepatuhan Wajib Pajak Orang Pribadi Yang Melakukan Kegiatan Usaha Dan Pekerjaan Bebas (Studi di Wilayah KPP Pratama Cilacap)". Diponegoro Journal Of Accounting Volume 1, Nomor.

Anisa Nirmala Santi. 2012. Analisis Pengaruh Kesadaran Perpajakan, Sikap Rasional, Lingkungan, Sanksi Denda dan Sikap Fiskus Terhadap Kepatuhan Wajib Pajak ( Studi Empiris Pada WPOP di Wilayah KPP Pratama Semarang). Skripsi. Semarang. Fakultas Ekonomi dan Bisnis Universitas Diponegoro.

Bandura, A,1986. Social foundations of thought and action. Englewood Cliffs, NJ: Prentice Hall.

Dharma \& Suardana (2014). Pengaruh Kesadaran Wajib Pajak, Sosialisasi Perpajakan, Kualitas Pelayanan Pada Kepatuhan Wajib Pajak, E-Jurnal Akuntansi Universitas Udayana; 2014 : 340-353

Devano, Sony, Siti Kurnia Rahayu. 2006. Perpajakan Konsep, Teori dan Isu. Jakarta: Prinadi Media Group.

Derwiza Ertrivana dkk (2016) pengaruh kesadaran wajib pajak, pengetahuan pajak dan sanksi perpajakan terhadap kepatuhan wajib pajak kendaraan bermotor di Kabupaten Sijunjung. Jurnal jurnal Akuntansi, Fakultas Ekonomi Universiatas Bung Hatta

Devano, S. Dan Rahayu, S. K. 2006. Perpajakan Konsep, Teori Dan Isu. JakartaPrenada Media. 
Jurnal Progres Ekonomi Pembangunan (JPEP)

Volume 5, Nomor 1, Tahun 2020

Page: $71-82$

http://ojs.uho.ac.id/index.php/JPEP

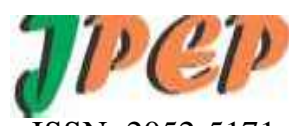

e-ISSN: 2052-5171

Gustina, Jumiati. 2014. Pengaruh Kesadaran Wajib Pajak, Pelayanan Fiskus dan Sanksi Pajak terhadap Kepatuhan Wajib Pajak Orang Pribadi yang Melakukan Kegiatan UKM. Skripsi. Fakultas Ekonomi. Universitas Bung Hatta.

Herry Susanto. 2012. Membangun Kesadaran dan Kepedulian Sukarela Wajib. Pajak.http://www.pajak.go.id/content/membangun-kesadaran-dan kepedulian-sukarelawajib-pajak

Irianto. 2010. Analisi Pengaruh Kesadaran Dan Kepatuhan Wajib http://respository.usu.ac.id. Diakses pada 03 Apri 2013.

I wayan Mustika Utama (2015) pengaruh kualitas pelayanan, sanksi perpajakan dan biaya kepatuhan terhadap kepatuhan wajib pajak kendaraan bermotor pada kantor bersama SAMSAT Tabanan jurnal.Fakultas Universitas Udayanan (unud), bali.

Isyatir, Anis Isnaini Nur.2015. Pengaruh Kualitas Pelayanan Fiskus dan Sanksi Pajak terhadap Kepatuhan Membayar Pajak Kendaraan Bermotor di Kabupaten Karanganyar.Jurnal Akuntansi Universitas Muhammadiyah Surakarta. http://eprints.ums.ac.id/35176/1/Naskah\%20Publikasi.pdf

Jatmiko, Agus Nugroho. 2006. "Pengaruh sikap wajib pajak pada pelaksanaan sanksi denda, pelayanan fiskus, dan kesadaran perpajakan terhadap kepatuhan wajib pajak". Tesis. Semarang: Program Studi Magister Akuntansi Pasca Sarjanan Universitas Diponegoro.

Kemala, Winda. 2015. Pengaruh Kesadaran Wajib Pajak, Pengetahuan Pajak, Sikap Wajib Pajak dan Reformasi Administrasi Perpajakan Terhadap Kepatuhan Wajib Pajak Kendaraan Bermotor. Fakultas Ekonomi Riau. Pekanbaru. Vol.2 No. 1. 2015.

Kiswanto. 2008. "pengaruh kualitas pelayanan terhadap kepuasan wajib pajak kesadaran bermotor di Kantor SAMSAT UPPD DIPENDA Provinsi Jawa Tengah Kabupaten Sragen”. Jurnal Daya Saing.

Muliari dan Setiawan. 2010. Pengaruh Persepsi Tentang Sanksi Perpajakan Dan Kesadaran Wajib Pajak Terhadap Kepatuhan Pelaporan Wajib Pajak. Skripsi. Universitas Udhayana Denpasar.

Mohammad Zain, 2004, Manajemen Perpajakan, Edisi Kedua, Jakarta: Salemba Empat.

Pandiangan, Liberty dan Robin.2013.Analisis FaktorFaktor yang Mempengaruhi Kepatuhan Wajib Pajak Orang Pribadi dalam Pemenuhan Kewajiban Pajak di KPP Pratama Setiabudi Tiga.EjurnalAkuntansi Universitas Bina Nusantara. Jakarta.

Rahayu, Siti Kurnia. 2010. Perpajakan Indonesia:Konsep dan Aspek Formal. Yogyakarta: Graha Ilmu.

Safri, Nurmantu. 2005. Pengantar Perpajakan (edisi 3). Jakarta: Granit.

Sari, R.A.Vivi Yulian dan Neri Susanti. 2013. Faktor-Faktor yang Mempengaruhi Kepatuhan Wajib Pajak Dalam Membayar Pajak Kendaraan Bermotor (PKB) di Unit Pelayanan Pendapatan Provinsi (UPPP) Kabupaten Seluma. Jurnal Review. Universitas Dehasen Bengkulu.

Sasongko, Hari Ajun. 2008. Pengaruh Akuntabilitas Pelayanan Publik Terhadap Pencapaian Target Penerimaan Pajak Kendaraan Bermotor Pada Kantor Bersama SAMSAT UPTD Kabupaten Tangerang Propinsi Banten. Skripsi Sarjana Akuntansi Fakultas Ekonomi Universitas Pembangunan Nasional Veteran.

Siti Kurnia Rahayu. 2010. Perpajakan Indonesia Konsep \& Aspek Formal. Yogyakarta : Graha Ilmu.

Undang-Undang Republik Indonesia Nomor 16 tahun 2009 tentang Ketentuan Umum dan Tata Cara Perpajakan.

Undang-Undang Republik Indonesia Nomor 28 tahun 2009 tentang Pajak Daerah dan Retribusi Daerah. 